\title{
ANALISIS KEMAMPUAN PEMAHAMAN KONSEP MATEMATIKA SISWA DALAM MENYELESAIKAN SOAL HOTS BERDASARKAN TAKSONOMI SOLO
}

\author{
Auliyau Rohman ${ }^{\text {a }}$, Luluk Faridah ${ }^{\mathrm{b}}$, Khafidhoh Nurul Aini ${ }^{\mathrm{c}}$ \\ ${ }^{a}$ Program Studi Pendidikan Matematika Universitas Islam Darul 'Ulum Lamongan, \\ auliyaurohman7@gmail.com, Jl. Airlangga No.03 Sukodadi, Lamongan. \\ ${ }^{\mathrm{b}}$ Program Studi Pendidikan Matematika Universitas Islam Darul 'Ulum Lamongan, \\ lulukfaridah@unisda.ac.id, Jl. Airlangga No.03 Sukodadi, Lamongan. \\ ${ }^{c}$ Program Studi Pendidikan Matematika Universitas Islam Darul 'Ulum Lamongan, \\ khafidhohnurul@unisda.ac.id, Jl. Airlangga No.03 Sukodadi, Lamongan.
}

\begin{abstract}
ABSTRAK
Penelitian ini bertujuan untuk mengetahui kemampuan pemahaman konsep siswa dalam menyelesaikan soal HOTS berdasarkan taksonomi SOLO. Adapun pemahaman konsep siswa yang dianalisis yaitu (1) menyatakan ulang konsep, (2) mengklasifikasikan objek menurut sifat-sifat tertentu, (3) menggunakan dan memanfaatkan serta memilih prosedur atau operasi tertentu, (4) menyajikan konsep dalam berbagai bentuk representasi matematis, (5) memberikan contoh dan non contoh dari suatu konsep, (6) mengembangkan syarat perlu atau cukup dari suatu konsep, (7) mengaplikasikan konsep atau logaritma dalam pemecahan masalah. Subjek penelitian ini adalah 15 siswa MTs Model A'isyatul Wahidah kelas VIII yang terbagi dalam 3 level yaitu unistructural, multistructural dan relational. Soal yang diberikan berupa 2 soal essay (uraian) yang memenuhi indikator HOTS dan pemahaman konsep. Dari tes ini dapat dilihat indikator-indikator dari pemahaman konsep. Setiap data yang diperoleh dianalisis dalam bentuk deskriptif.
\end{abstract}

Kata Kunci: Kemampuan Pemahaman Konsep, Soal HOTS, Taksonomi SOLO.

\begin{abstract}
This study discusses students' understanding of the completion of HOTS based on the SOLO taxonomy. When understanding the concepts of students being analyzed namely (1) restate the concept, (2) classify objects based on certain traits, (3) use and utilize and choose certain procedures or operations, (4) 5) provide examples and not examples of an concept, (6) developing the necessary or sufficient requirements of a concept, (7) applying a concept or logarithm in problem solving. The subjects of this study were 15 students of MTs Model A'isyatul Wahidah class VIII which were divided into 3 levels: unistructural, multistructural and relational. The questions given consist of 2 essay questions (descriptions) that meet HOTS indicators and concept understanding. From this test can be seen indicators of understanding the concept. Each data obtained was analyzed in a descriptive form.
\end{abstract}

Keywords: Concept Understanding Ability, HOTS Questions, SOLO Taxonomy. 


\section{PENDAHULUAN}

Pada era global seperti saat ini, ilmu pengetahuan dan teknologi mengalami kemajuan yang pesat. Tidak dapat dipungkiri bahwa hal tersebut juga dipengaruhi oleh peran matematika sebagai salah satu cabang ilmu pengetahuan yang mendasari perkembangan ilmu pengetahuan yang lain. Matematika merupakan salah satu mata pelajaran pokok yang diajarkan di sekolah baik di tingkat dasar, menengah, dan atas. Maka tidak mengherankan jika matematika dianggap sebagai salah satu cabang ilmu yang penting untuk diajarkan setiap jenjang pendidikan. Matematika perlu diajarkan kepada siswa karena selalu digunakan dalam segi kehidupan, semua bidang memerlukan keterampilan matematika, dan matematika dapat meningkatkan kemampuan pemecahan masalah, sistematis, logis, dan kreatif. Peran matematika dalam kehidupan sehari-hari tersebut menjadikan matematika sebagai Queen of Science.

Secara umum, tujuan pembelajaran matematika menurut kurikulum tingkat satuan pendidikan (BSNP) adalah memberikan penekanan pada penataan nalar, pembentukan sikap siswa, dan keterampilan pemecahan masalah dalam penerapan matematika, baik dalam kehidupan sehari-hari maupun dalam membantu mempelajari ilmu pengetahuan lainnya. Tercapainya tujuan pembelajaran dalam matematika dapat dilihat dari prestasi siswa dalam mencapai setiap indikator pada materi pelajaran.

Pembelajaran matematika sangat diperlukan karena terkait dengan pemahaman sistematis. Salah satu yang menjadi awal keberhasilan pembelajaran matematika ialah pemahaman konsep. Pemahaman konsep perlu ditanamkan pada siswa sejak pertama kali menerima materi tentang matematika di tingkat pendidikan dasar. Mereka dituntut untuk mengerti definisi, pengertian, cara mengoprasikan matematika dengan benar, dan menggunakan konsep tersebut dalam pemecahan masalah dalam matematika. Hal itu akan menjadi bekal untuk mempelajari matematika pada jenjang pendidikan yang lebih tinggi. Siswa yang memiliki pemahaman konsep yang bagus dapat memecahkan masalah dengan mudah.

Suherman (dalam Zevika, dkk: 2012) menjelaskan bahwa topik atau konsep prasyarat dalam matematika dijadikan sebagai dasar untuk memahami topik atau konsep selanjutnya. Kemampuan pemahaman konsep matematika juga merupakan hal penting karena dalam matematika mempelajari konsep atau topik secara 
berkesinambungan dan saling terhubung. Zevika, dkk. (2012:49) menyimpulkan bahwa pemahaman konsep merupakan hal yang dibutuhkan dalam mencapai hasil belajar yang baik. Siswa dikatakan telah mempunyai kemampuan pemahaman konsep yang baik, apabila mereka dapat menunjukkan indikator-indikator pemahaman konsep dalam tes. Pemahaman konsep sendiri bisa secara efektif meningkat dengan penerapan pembelajaran berbasis masalah (Mudhiah \& Shodikin, 2019).

Namun pada kenyataan di lapangan, berdasarkan pengalaman dan pengamatan peneliti, siswa sangat sulit untuk belajar matematika. Terlihat bahwa motivasi siswa dalam mengikuti pembelajaran matematika masih kurang. Hanya beberapa siswa saja yang berperan aktif dan cenderung menonjolkan diri sehingga peran siswa dalam pembelajaran belum merata. Begitu juga dengan soal yang diberikan oleh guru, siswa kurang mempunyai keinginan untuk mengerjakannya. Siswa yang bersemangat untuk mengerjakan hanya hitungan jari, sedangkan yang lainnya hanya menunggu pekerjaan teman bahkan ada yang sama sekali tidak mengerjakan. Ketika guru mengajukan pertanyaan hanya beberapa siswa saja yang berusaha menjawab dan siswa yang menjawab cenderung sama, padahal guru sudah memberikan kesempatan kepada semua siswa.

$$
\text { Sejalan dengan tujuan }
$$
pembelajaran matematika, siswa juga dituntut untuk menggunakan keterampilan berpikirnya. Diantaranya menguasai keterampilan berpikir dari tingkat rendah atau LOTS (Lower Order Thinking Skill) hingga keterampilan berfikir tingkat tinggi atau HOTS (Higher Order Thinking Skill). Menurut A. Thomas \& G. Thorne (dalam Gunawan, 2008) LOTS adalah keterampilan berpikir yang hanya menuntut seseorang untuk mengingat, memahami, dan mengaplikasikan sesuatu rumus atau hukum. Sedangkan HOTS adalah keterampilan yang lebih dari sekedar mengingat, memahami, dan mengaplikasikan (Rosnawati, 2005). Terkadang HOTS juga disebut pula sebagai gabungan dari berpikir kritis, berpikir kreatif dan berpikir pengetahuan. Oleh karena itu, dalam menggunakan keterampilan berpikir tingkat tinggi seseorang harus berpikir lebih dari sekedar mengingat, memahami, dan mengaplikasikan sesuatu rumus saja.

Berdasarkan hasil tes PISA (Programme for International Student Assesment) pada tahun 2015, kemampuan matematis siswa di Indonesia menduduki peringkat ke-63 dari 71 negara dengan 
skor 387 yang sangat jauh dengan nilai rata-rata yaitu 490. Hal itu menunjukkan bahwa siswa masih lemah dalam menyelesaikan soal-soal yang berkaitan dengan kemampuan analisis, evaluasi, kreasi, serta logika dan penalaran.

Selain itu, para pengajar juga dituntut untuk bisa membimbing para siswa agar menyelesaikan masalah tersebut. Salah satunya dengan melakukan evaluasi terhadap hasil belajar dengan menilai pemahaman konsep siswa dalam menyelesaikan suatu masalah. Oleh karena itu, untuk menetahui siswa tersebut paham terhadap konsep atau tidak, dibutuhkan suatu alat untuk menganalisis kemampuan siswa dalam menyelesaikan suatu masalah. Fungsi dari alat tersebut adalah mengetahui kemampuan siswa saat menyelesaikan permasalahan matematika berdasarkan kriteria/tingkatan. Alat tersebut adalah taksonomi SOLO (Structure of the Observed Learning Outcome) yang memiliki lima level struktur hasil belajar siswa. Taksonomi SOLO digunakan untuk mengukur kemampuan siswa dalam merespon suatu tugas. Menurut John Biggs dan Kevin Collin kelima level tersebut yaitu prestructural (level 0), unistructural (level 1), multistructural (level 2), relational (level 3), dan extended abstract (level 4).

\section{METODE PENELITIAN}

Jenis penelitian yang digunakan dalam penelitian ini adalah penelitian deskriptif dengan pendekatan kualitatif. Penelitian kualitatif deskriptif dilakukan dengan cara mendeskripsikan dan menganalisis hasil yang diperoleh saat penelitian. Instrumen yang digunakan terdiri dari instrumen utama dan instrumen pendukung. Instrumen utama merupakan peneliti itu sendiri, sedangkan instrumen pendukungnya adalah instrumen HOTS, instrumen tes Taksonimi SOLO, dan instrumen pedoman wawancara.

Penelitian dilakukan di kelas VIII MTs Model A'isyatul Wahidah yang terdiri dari 15 siswa pada semester genap Tahun Pelajaran 2019/2020. Subjek penelitian ini yaitu 10 siswa kelas VIII. Penentuan subjek penelitian menggunakan instrumen Taksonomi SOLO untuk mengetahui kemampuan berpikir siswa sesuai dengan levelnya.. Subjek penelitian tersebut kemudian diberikan tes soal HOTS dilanjutkan dengan wawancara.

\section{HASIL DAN PEMBAHASAN}

\section{Hasil Penelitian}

Pemilihan subjek dilakukan dengan mempertimbangkan hasil tes instrumen Taksonomi SOLO yang terdiri dari 4 pertanyaan uraian. Apabila subjek 
dapat menjawab pertanyaan soal nomor 1 dengan benar maka subjek tersebut tergolong level Unistructural. Jika dapat menjawab pertanyaan soal nomor 2 dengan benar maka subjek tersebut tergolong level Multistructural dan seterusnya.

Berdasarkan data yang telah terkumpul, peneliti kemudian mengklasifikasikan siswa sesuai dengan level Taksonomi SOLO. Pengklasifikasian level Taksonomi SOLO kelas VIII dapat dilihat pada tabel sebagai berikut:

Tabel 1. Klasifikasi Tahapan Berpikir Van Hiele

\begin{tabular}{|l|c|}
\hline $\begin{array}{c}\text { Tingkatan } \\
\text { Taksonomi SOLO }\end{array}$ & JUMLAH \\
\hline Unistructural & 7 siswa \\
\hline Multistructural & 5 siswa \\
\hline Relational & 3 siswa \\
\hline \multicolumn{1}{|c|}{ Jumlah } & 15 siswa \\
\hline
\end{tabular}

Berdasarkan Tabel 1 diketahui bahwa dari keseluruhan jumlah siswa kelas VIII MTs Model A'isyatul Wahidah Tahun Pelajaran 2019/2020 yang berjumlah 15 siswa, 7 siswa berada pada level Unistructural, 5 siswa berada pada level Multistructural dan 3 siswa berada pada level Relational. Untuk level Prastructural tidak ada siswa yang tidak mengisi semua jawaban dan untuk level Extended Abstract dapat dikatakan belum dapat dicapai oleh semua siswa.
Hasil pengklasifikasian level Taksonomi SOLO tersebut dapat disajikan dengan diagram persentase sebagai berikut:

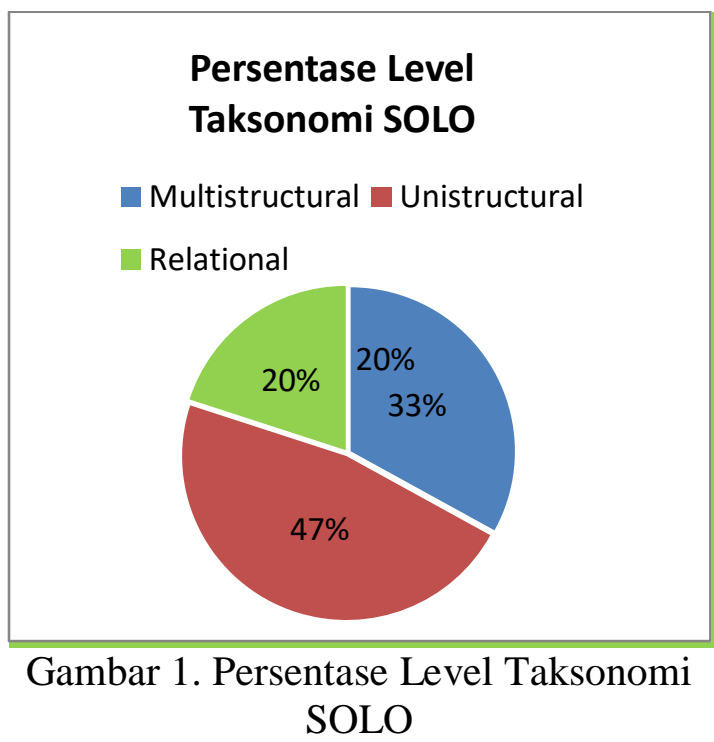

Berdasarkan hasil pengklasifikasian tersebut, masingmasing dari level Taksonomi SOLO diambil 2 siswa sebagai subjek penelitian. Adapun subjek penelitian tersebut terdiri atas 2 siswa dengan level Unistructural, 2 siswa dengan level Multistructural, dan 2 siswa dengan level Relational. Adapun daftar subjek penelitian dapat dilihat pada tabel berikut.

Tabel 2. Daftar Subjek Penelitian

\begin{tabular}{|c|c|}
\hline LEVEL & KODE \\
TAKSONOMI SOLO & SUBJEK \\
\hline \multirow{2}{*}{ Unistructural } & U1 \\
\cline { 2 - 2 } & $\mathrm{U} 2$ \\
\hline \multirow{2}{*}{ Multistructural } & $\mathrm{M} 1$ \\
\cline { 2 - 2 } & $\mathrm{M} 2$ \\
\hline \multirow{2}{*}{ Relational } & $\mathrm{R} 1$ \\
\cline { 2 - 2 } & $\mathrm{R} 2$ \\
\hline
\end{tabular}




\section{Pembahasan}

Kemampuan pemahaman konsep siswa dalam menyelesaikan soal HOTS dianalisis sesuai dengan indikator pemahaman konsep yang digunakan peneliti yaitu menyatakan ulang konsep dan mengklasifikasikan objek menurut sifat-sifat tertentu, menggunakan dan memanfaatkan serta memilih prosedur atau operasi tertentu, menyatakan konsep dalam berbagai bentuk representasi matematis, memberikan contoh dan bukan contoh dari suatu konsep, mengembangkan syarat perlu atau cukup dari suatu konsep, dan mengaplikasikan konsep atau logaritma dalam pemecahan masalah. Hasil dan pembahasan kemampuan pemahaman konsep siswa dalam menyelesaikan soal HOTS berdasarkan taksonomi SOLO adalah sebagai berikut.

\section{Kemampuan Pemahaman Konsep}

\section{Siswa dalam Menyelesaikan Soal}

\section{HOTS Berdasarkan Taksonomi}

SOLO Level Unistructural

Berdasarkan data yang diperoleh dari hasil tes tulis dan wawancara dapat diketahui bahwa subjek dengan kemampuan pemahaman konsep level unistructural dapat memenuhi lima indikator pemahaman konsep.

Subjek U1 mampu memahami indikator pemahaman konsep antara lain, (1) menyatakan ulang konsep, (2) mengklasifikasikan objek menurut sifatsifat tertentu sesuai dengan konsepnya, (3) menggunakan dan memanfaatkan serta memilih prosedur tertentu, (4) menyajikan konsep dalam berbagai bentuk representasi matematis, (7) mengaplikasikan konsep atau logaritma dalam pemecahan masalah. Subjek U1 kurang mampu memahami indikator (5) memberikan contoh dan non contoh dari suatu konsep, dalam tes tulis subjek U1 hanya mampu memberikan contoh dan belum menyertakan non contohnya. Serta pada wawancara Subjek U1 mampu menyebutkan yang bukan non contoh dengan benar. Pada indikator mengembangkan syarat perlu atau cukup dari suatu konsep, subjek U1 langsung memilih kardus yang paling besar, tanpa menghitung volumenya terlebih dahulu. Sedangkan subjek U2 mampu memahami indikator pemahaman konsep antara lain, (1) menyatakan ulang konsep, mengklasifikasikan objek menurut sifatsifat tertentu sesuai dengan konsepnya, (3) menggunakan dan memanfaatkan serta memilih prosedur tertentu, (4) menyajikan konsep dalam berbagai bentuk representasi matematis, (7) mengaplikasikan konsep atau logaritma dalam pemecahan masalah. Subjek U2 kurang mampu memahami indikator (5) memberikan contoh dan non contoh dari suatu konsep, dalam tes tulis subjek U2 
hanya mampu memberikan contoh dengan benar dan menuliskan non contoh yang salah. Serta pada wawancara Subjek U2 mampu menyebutkan yang bukan non contoh dengan benar. Pada indikator (6) mengembangkan syarat perlu atau cukup dari suatu konsep, subjek U2 langsung memilih kardus yang paling besar, tanpa menghitung volumenya terlebih dahulu. Maka dapat disimpulkan bahwa subjek U1 dan U2 memiliki tingkat pemahaman konsep yang sama.

\section{Kemampuan Pemahaman Konsep}

Siswa dalam Menyelesaikan Soal

HOTS Berdasarkan Taksonomi

\section{SOLO Level Multistructural}

Berdasarkan data yang diperoleh dari hasil tes tulis dan wawancara dapat diketahui bahwa subjek dengan kemampuan pemahaman konsep level multistructural dapat memenuhi enam indikator pemahaman konsep.

Subjek M1 mampu memahami indikator pemahaman konsep antara lain, (1) menyatakan ulang konsep, (2) mengklasifikasikan objek menurut sifatsifat tertentu sesuai dengan konsepnya, (3) menggunakan dan memanfaatkan serta memilih prosedur tertentu, (4) menyajikan konsep dalam berbagai bentuk representasi matematis, (7) mengaplikasikan konsep atau logaritma dalam pemecahan masalah. Subjek M1 kurang mampu memahami indikator (5) memberikan contoh dan non contoh dari suatu konsep, dalam tes tulis subjek M1 hanya mampu memberikan contoh dengan benar dan menuliskan non contoh yang salah. Serta pada wawancara Subjek M1 mampu menyebutkan yang bukan non contoh dengan benar. Pada indikator (6) mengembangkan syarat perlu atau cukup dari suatu konsep, subjek M1 langsung memilih kardus yang paling besar, tanpa menghitung volumenya terlebih dahulu. Sedangkan subjek M2 mampu memahami indikator pemahaman konsep antara lain, (1) menyatakan ulang konsep, (2) mengklasifikasikan objek menurut sifat-sifat tertentu sesuai dengan konsepnya, (3) menggunakan dan memanfaatkan serta memilih prosedur tertentu, (4) menyajikan konsep dalam berbagai bentuk representasi matematis, (5) memberikan contoh dan non contoh dari suatu konsep, (7) mengaplikasikan konsep atau logaritma dalam pemecahan masalah. Subjek M2 kurang mampu memahami indikator indikator mengembangkan syarat perlu atau cukup dari suatu konsep, subjek M2 langsung memilih kardus yang paling besar, tanpa menghitung volumenya terlebih dahulu. Maka dapat disimpulkan bahwa subjek M1 dan M2 memiliki tingkat pemahaman konsep yang hampir sama.

3. Kemampuan Pemahaman Konsep Siswa dalam Menyelesaikan Soal 


\section{HOTS Berdasarkan Taksonomi SOLO Level Relational}

Berdasarkan data yang diperoleh dari hasil tes tulis dan wawancara dapat diketahui bahwa subjek dengan kemampuan pemahaman konsep level relational dapat memenuhi tujuh indikator pemahaman konsep.

Subjek R1 mampu memahami indikator pemahaman konsep antara lain, (1) menyatakan ulang konsep, mengklasifikasikan objek menurut sifatsifat tertentu sesuai dengan konsepnya, (3) menggunakan dan memanfaatkan serta memilih prosedur tertentu, (4) menyajikan konsep dalam berbagai bentuk representasi matematis, mengembangkan syarat perlu atau cukup dari suatu konsep, (7) mengaplikasikan konsep atau logaritma dalam pemecahan masalah. Subjek R1 kurang mampu memahami indikator (5) memberikan contoh dan non contoh dari suatu konsep, dalam tes tulis subjek R1 hanya mampu memberikan contoh dengan benar dan menuliskan non contoh yang salah. Serta pada wawancara Subjek R1 mampu menyebutkan yang bukan non contoh dengan benar. Sedangkan subjek R2 mampu memahami semua indikator pemahaman konsep antara lain, (1) menyatakan ulang konsep, (2) mengklasifikasikan objek menurut sifat- sifat tertentu sesuai dengan konsepnya, (3) menggunakan dan memanfaatkan serta memilih prosedur tertentu, (4) menyajikan konsep dalam berbagai bentuk representasi matematis, memberikan contoh dan non contoh dari suatu konsep, (6) mengembangkan syarat perlu atau cukup dari suatu konsep, (7) mengaplikasikan konsep atau logaritma dalam pemecahan masalah. Maka dapat disimpulkan bahwa subjek R1 dan R2 memiliki tingkat pemahaman konsep yang hampir sama.

\section{PENUTUP}

\section{Simpulan}

Berdasarkan analisis dan pembahasan mengenai kemampuan pemahaman konsep siswa dalam menyelesaikan soal HOTS berdasarkan taksonomi SOLO dapat disimpulkan:

1. Pada level prestructural, tidak ada siswa yang masuk ke dalam level ini. Hal itu karena semua siswa mampu menjawab soal minimal sampai level unistructural. Sehingga tidak ada siswa yang tidak mengisi jawaban sama sekali atau masuk ke dalam level prestructural.

2. Pada level unistructural, terdapat dua subjek yaitu U1 dan U2. Di mana subjek U1 mampu memahami 5 indikator pemahaman konsep dari 7 indikator. Sedangkan subjek U2 juga 
mampu memahami 5 indikator pemahaman konsep dari 7 indikator.

3. Pada level multistructural, terdapat dua subjek yaitu M1 dan M2. Di mana subjek M1 mampu memahami 5 indikator pemahaman konsep dari 7 indikator. Sedangkan subjek M2 mampu memahami 6 indikator pemahaman konsep dari 7 indikator.

4. Pada level relational, terdapat dua subjek yaitu R1 dan R2. Di mana subjek R1 mampu memahami 6 indikator pemahaman konsep dari 7 indikator. Sedangkan subjek R2 mampu memahami 7 indikator pemahaman konsep dari 7 indikator.

5. Pada level extended abstract, tidak ada siswa yang masuk ke dalam level ini. Hal itu karena siswa hanya mampu menjawab soal maksimal sampai level relational. Sehingga dapat dikatakan level extended abstract belum dapat dicapai oleh semua siswa.

\section{Saran}

Berdasarkan temuan yang penulis temukan dalam penelitian ini, ada beberapa saran penulis terkait penelitian ini, diantaranya:

1. Bagi sekolah, dengan adanya hasil penelitian ini hendaknya dapat dijadikan masukan dan pertimbangan sebagai salah satu bahan alternatif dalam kemajuan semua mata pelajaran terutama pelajaran matematika serta bisa dijadikan acuan untuk lebih meningkatkan kemampuan pemahaman konsep.

2. Bagi guru matematika, hendaknya lebih sering memberi contoh-contoh soal HOTS kepada siswa supaya siswa terbiasa dan terlatih dengan soal bertipe HOTS.

3. Bagi siswa, hendaknya memiliki kemauan untuk berlatih mengerjakan soal secara rutin serta mendalami kembali materi yang telah disampaikan guru sehingga tidak melakukan kesalahan saat mengerjakan soal yang diberikan.

\section{DAFTAR PUSTAKA}

Al'Azzy, U.L. \& Budiono, E. (2013). Penerapan Strategi Brain Based Learning yang Dapat Meningkatkan Keterampilan Berpikir Tingkat Tinggi. Universitas Negeri Malang.

Arikunto, Suharsimi. (2013). Prosedur Penelitian Suatu Pendekatan Praktik. Jakarta: Rineka Cipta.

Biggs, John and Kevin Collis. (1982). Evaluating The Quality of Learning The SOLO Taxonomy (Structure of the Observed Learning Outcome). New York: Academic Press.

Dafril, A. (2011). Pengaruh Pendekatan Konstruktivisme Terhadap Peningkatan Pemahaman Matematika Siswa. Prosiding PGRI. Palembang.

Dian, Kurniati, dkk. (2016). Kemampuan Berpikir Tingkat Tinggi Siswa 
SMP di Kabupaten Jember Dalam Menyelesaikan Soal Berstandar Pisa. Jurnal Penelitian dan Evaluasi Pendidikan.

Kemendikbud. (2017). Modul Penyusunan Soal Higher Order Thinking Skill (HOTS). Dirjen Pendidikan Dasar dan Menengah.

Lewy, Zulkardi, dan Nyimas Aisyah. (2009). Pengembangan Soal Untuk Mengukur Kemampuan Berpikir Tingkat Tinggi Pokok Bahasan Barisan dan Deret Bilangan Di Kelas IX Akselerasi SMP Xaverius Maria Palembang. Jurnal Pendidikan Matematika. Vol. 3(2).

Moelong, J Lexy. 2015. Metodologi Penelitian Kualitatif. Bandung: PT Remaja Rosdakarya.

Mudhiah, S., \& Shodikin, A. (2019). Pengaruh Model Pembelajaran Berbasis Masalah Terhadap Kemampuan Pemahaman Konsep dan Penalaran Geometris Siswa. Jurnal Elemen, Vol. 5(1), pp. 43-53.

OECD. (2016). PISA 2015 Result in Focus. (Online), tersedia: (http://www.oecd.org/pisa), diakses pada tanggal 15 April 2020.

Rosnawati, (2005). Pembelajaran Matematika yang Mengembangkan Berpikir Tingkat Tinggi. Makalah. Disampaikan dalam Seminar Nasional.

Sani, A. R. (2019). Strategi Belajar Mengajar. Depok: Rajawali Press.

Sanjaya, W. (2009). Strategi Pembelajaran Berorentasi Standar Proses Pendidikan. Jakarta: Kencana Prenada Media Group.

Shadiq, F. (2009). Kemahiran Matematika. Yogyakarta: Departemen Pendidikan Nasional Direktorat Jendral Peningkatan Mutu Pendidik dan Tenagan Kependidikan Pusat
Pengembangan dan Penataran Guru Matematika.

Sudjiono, A. (2013). Pengantar Evaluasi Pendidikan. Jakarta: PT Raja Grafindo Persada.

Sugiyono. (2015). Metode Penelitian Pendidikan: Pendekatan Kuantitatif, Kualitatif, dan $R \& D$. Bandung: Alfabeta.

Suryapuspitarini, Betha, dkk. (2018). Analisis Soal-Soal Matematika Tipe Higher Order Thinking Skill (HOTS) pada Kurikulum 2013 untuk Mendukung Kemampuan Literasi Siswa. PRISMA (Prosiding Seminar Nasional Matematika).

Tanzeh, Ahmad. (2011). Metodologi Penelitian Praktis. Yogyakarta: Teras.

Tomei, L.A. (2005). Taxonomy for the Technology Domain. Hershey: Information Science Publishing.

Wardhani, S. (2008). Analisis SI dan SKL Mata Pelajaran Matematika SMP/MTS. Yogyakarta: Pusat Pengembangan dan Pemberdayaan Pendidik dan Tenaga Kependidikan Matematika.

Widyawati, A., dkk. (2018). Analisis Kesalahan Siswa dalam Memecahkan Masalah Lingkaran Berdasarkan Taksonomi Solo Pada Kelas VIII. Jurnal Pendidikan Matematika dan Sains.

Zevika, M., dkk. (2012). Meningkatkan Kemampuan Pemahaman Konsep Siswa Kelas VIII SMP Negeri 2 Padang Panjang Melalui Pembelajaran Kooperatif Tipe Think Pair Share I Disertai Peta Pikiran. Jurnal Pendidikan Matematika. 